BULLETIN Bulletin hispanique

HISPANIQUE Université Michel de Montaigne Bordeaux

112-1| 2010

Actes du Colloque « langue, littérature, littéralité »

\title{
La especificidad del lenguaje gongorino
}

\section{Antonio Carreira}

\section{OpenEdition}

\section{Journals}

Edición electrónica

URL: http://journals.openedition.org/bulletinhispanique/1107

DOI: 10.4000/bulletinhispanique.1107

ISSN: 1775-3821

\section{Editor}

Presses universitaires de Bordeaux

\section{Edición impresa}

Fecha de publicación: 1 junio 2010

Paginación: 89-112

ISBN: 978-2-86781-692-5

ISSN: 0007-4640

\section{Referencia electrónica}

Antonio Carreira, «La especificidad del lenguaje gongorino », Bulletin hispanique [En línea], 112-1 |

2010, Publicado el 01 junio 2013, consultado el 10 diciembre 2020. URL : http://

journals.openedition.org/bulletinhispanique/1107; DOI : https://doi.org/10.4000/bulletinhispanique. 1107 


\title{
La especificidad del lenguaje gongorino
}

\author{
Antonio Carreira \\ Madrid
}

Examen de quelques procédés rhétoriques du langage de Góngora, dont la maîtrise a dû séduire ses premiers lecteurs, et a contribué à asseoir la réputation du poète, alors que la plus grande partie de son auvre était encore inédite.

Examen de algunos recursos retóricos del lenguaje de Góngora, cuya maestría puede haber llamado la atención de sus primeros lectores, contribuyendo a cimentar la fama del poeta cuando la mayor parte de su obra estaba aún inédita.

This article will examine some of the rhetorical resources used by Gongora to create his poetic language. His absolute mastery of these resources may well have attracted the attention of his first readers, thereby assuring the poet's fame at a time when the greater part of his work was still unpublished.

Mots-clés : Espagne - Poésie - Góngora - Rhétorique - Polygenèse - Monogenèse.

C IN duda es mucha audacia pretender fijar, aunque sea parcialmente, lo $\checkmark$ que haya de específico en el lenguaje gongorino, sobre todo después de Nadine Ly y Mercedes Blanco, quienes más han hecho por dilucidarlo con

$B H i$, Tome 112, n 1 - juin 2010 - p. 89 à 112. 
los ojos de Gracián, tal como recomendaba Maurice Molho ${ }^{1}$. Sin embargo, nuestra intención será más modesta: descubrir la poesía de Góngora con unos ojos todavía no disciplinados por la teoría sino afincados en la intuición: los de sus primeros lectores. Dicho de otro modo, nos gustaría averiguar por qué la poesía de Góngora fue considerada algo excepcional, desde muy pronto, por gentes que desconocían los tratados italianos o vernáculos, luego aducidos para atacarla o defenderla. Quisiéramos encontrar la razón de su

1. De ambas gongoristas enumeramos aquí los trabajos más relacionados con nuestro asunto: Nadine Ly, «Oralité et Solitudes», Les Cahiers de Fontenay, 34 (1984), p. 59-82; "Poétique et signifiant linguistique. À propos d'un fragment des Soledades», BHi, LXXXVII (1985), p. 447-470; «Las Soledades: esta poesía inútil», Criticón, 30 (1985), p. 7-42; «La confusión: léxico, retórica y significado en la poesía de Góngora», Homenaje a Antonio Vilanova (Barcelona, 1989), I, p. 355-375; «La grande clarté des Soledades. De l'imitation à l'intertextualité: traditio", F. Cerdan y M. Vitse (eds.), Autour des Solitudes / En torno a las Soledades de Luis de Góngora (Toulouse: PUM, 1995), p. 67-80; "Tradición, memoria, literalidad: el caso de Góngora», $B H i$, XCVII (1995), p. 347-359; «Anacoluthe et grammaire: la syntaxe du morphème que dans les Soledades de Góngora», M. Moner y J.-P. Clément (eds.), Hommage à Henry Bonneville (Tours, 1996), p. 301-330; «La espuma de un mar común: la autocita como motor de la escritura en Góngora», Varia lingüistica y literaria. 50 años del CELL (México, 1998), p. 243-274; «El orden de las palabras: orden lógico, orden analógico (la sintaxis figurativa en Las Soledades)», BHi, CI (1999), p. 219-246; «Propiedad lingüística y verdad de las cosas: deleyte de la palabra, deleyte de la cosa. (A propósito del anti-barroquismo de Machado)», J. Roses (ed.), Góngora hoy, I-III (Córdoba: Diputación, 2002), p. 145-177; «Gramática gongorina del hypérbaton (De poética, artículos, pronombres e hipérbatos, 16091615)», B. López Bueno (ed.), El poeta Soledad (Zaragoza: Prensas Universitarias, 2010), en prensa.

Mercedes Blanco, Les Rhétoriques de la Pointe. Baltasar Gracián et le Conceptisme en Europe, Paris: Champion, 1992; «Les Solitudes comme système de figures. Le cas de la synecdoque», J. Issorel (ed.), Crepúsculos pisando. Once estudios sobre las Soledades de Góngora. Marges, no 16 (1995), p. 23-78; «Le burlesque mythologique de Góngora. À propos de la fable de Pyrame et Thysbé», A. Montandon y D. Bertrand (eds.), Poétiques du burlesque (París: Champion, 1998), p. 219-242; «Lienzo de Flandes: las Soledades y el paisaje pictórico», Actas del IV Congreso de la AISO (Alcalá de Henares: Universidad, 1998), I, p. 263-274; «Góngora reescritor de ficciones», G. Grilli (ed.), Modelli, memorie, riscritture (Nápoles, 2001), p. 309338; «Góngora y el concepto», J. Roses (ed.), Góngora hoy, I-III (Córdoba: Diputación, 2002), p. 319-346; «Fragmentos de un discurso satírico en Góngora», C. Vaíllo y R. Valdés (eds.), Estudios sobre la sátira española en el siglo de oro (Madrid: Castalia, 2006), p. 11-34; «Góngora o la libertad del ingenio», J. Roses (ed.), Góngora hoy, VIII (Córdoba: Diputación, 2006), p. 17-38; «El toro nupcial de la Soledad primera. Idiolecto y agudeza en la poética barroca de las Soledades", AA. VV., Congreso Internacional Andalucía Barroca (Sevilla: Junta de Andalucía, 2009), p. 41-52; «La estela del Polifemo, o el florecimiento de la fábula barroca (1613-1624)», A. Bègue y J. Ponce (eds.), La fábula mitológica barroca. Comentarios y nuevas perspectivas, en prensa; "Góngora et la querelle de l'hyperbate», BHi: Langue, littérature, littéralité. Hommage à Nadine Ly (2010), en prensa. 
calidad, pues no parece aceptable que sea algo subjetivo, cuando tantos en su tiempo y en el nuestro coincidieron al apreciarla.

Góngora, en su juventud, habrá leído lo que cayera en sus manos, que no debió de ser mucho, a juzgar por la sorna con que, en prosa o verso, recuerda sus estudios. En su poesía habla poco de libros, y casi siempre en broma; menos aún en sus cartas, y en su testamento ni los menciona; es de suponer que la biblioteca paterna, con el resto de los bienes civiles familiares, la había heredado su hermano Juan. Por otra parte, alguien que necesita comprar un cartapacio con sus poesías, cuando en sus últimos ańos piensa publicarlas para salir de apuros, no es ningún ratón de biblioteca; su actitud no concuerda con la de tantos otros que atesoraban libros y manuscritos. Góngora da la impresión de vivir al margen, no de la literatura, sino de su materialidad. En su obra se han detectado, ya desde antiguo, multitud de ecos, de clásicos o de italianos, no pocos de los cuales, como alguna vez reconoció Antonio Vilanova, solo son resultado de poligénesis. La vida que llevó no fue la propia de un erudito empeñado en hacer gemir las prensas, sino la de un clérigo vividor, con muchas horas diarias ocupadas en su oficio, desde los 25 años, y bastantes dedicadas a aficiones más mundanas como el naipe y los viajes. Y tampoco parece probable que haya cambiado de hábitos a partir de 1611, cuando sus rentas se redujeron a la mitad, ni desde 1617, fecha en que se traslada a Madrid y comienza a sufrir sus mayores agobios económicos ${ }^{2}$. Quevedo pudo pintar su vida en La Torre con el soneto «Retirado en la paz de estos desiertos / con pocos pero doctos libros juntos", libros que sus obras comentan o dejan entrever. De Góngora cualquiera recuerda declaración similar: "Con pocos libros libres (libres, digo, / de expurgaciones), paso y me paseo, / ya que el tiempo me pasa como higo", pero en esos versos los libros comparecen sobre todo para permitir el juego de palabras, pues en toda la obra de Góngora no hay la menor huella de ningún libro expurgable. Dos años más tarde, al añorar desde Madrid su vida anterior, con lenguaje menos elaborado, lo que evoca es lo siguiente: «Córdoba y tres mil ducados de renta en mi patinejo, mis fuentes, mi breviario, mi barbero y mi mula» (carta de 30 de septiembre de 1613). Y todo hace sospechar que ese breviario antepuesto al barbero y la mula tampoco era su libro de cabecera; recordemos que una vez que pretendió argüir echando mano de la Biblia, confundió el Nuevo Testamento con el Viejo. Lástima quizá, porque nuestra forma de acceder

2. Su amigo José Pérez de Ribas transmite unas palabras en que Góngora explica su querencia por Madrid: "Aquí me incitan motivos para trabajar, y a dejar el ocio con que Córdoba me persuade» (Escrutinio sobre las impresiones de las obras poéticas de don Luis de Góngora, en Góngora, Obras completas, ed. de J. e I. Millé y Giménez, Madrid: Aguilar, 1932, p. 1294). 
a Góngora deriva de la que nos enseñaron sus primeros comentaristas, para quienes el poeta apenas podía pergeñar un verso sin citar unos cuantos lugares prestigiosos, como si la creación poética fuese ante todo labor de taracea. Pero, si se excluyen los grandes poemas y los sonetos juveniles, ni la mayor parte de los romances, letrillas y décimas, ni los sonetos de madurez se prestan mucho a tales indagaciones intertextuales. Vagas reminiscencias aquí, un sintagma allí, y lo demás son parecidos aleatorios.

No estamos negando el influjo de distintos autores en Góngora, quien, mejor o peor, había leído su Virgilio, su Ovidio y su Claudiano, aparte de conocer bien la poesía italiana y aprovechar los recursos de ambas lenguas donde era oportuno. Pero, admitiendo la imitación o la poligénesis cuando son evidentes, nos interesa ahora más la monogénesis. El bagaje cultural no bastaba para dar alta calidad a una poesía (v. g., el Panegírico), que en cambio sin él podía alcanzarla, como sucede en el romancillo «Hermana Marica». Góngora no participó de la inevitable pedantería que arrastraba el humanismo, y que llevó a algunos a empedrar de citas el texto y los márgenes de sus obras, sino que, desechando aquel exhibicionismo, prefirió hacer funcionar poéticamente las cosas, dotadas o no de pedigree libresco. Cultura, por supuesto, pero sin dejarse ahogar por ella; culteranismo, si se quiere, ma non troppo. La poesía para Góngora no consistía en abofetear polianteas sino en dosificar y adecuar la forma de la expresión a la del contenido en un equilibrio fácil de apreciar aunque arduo de mantener y más aún de definir. $\mathrm{Al}$ pensar en sus lectores, como hacen todos los poetas, probablemente quiso más deleitarlos con su verso que deslumbrarlos con su sapiencia, y por eso se equivocó al creer que su obra era «no para los muchos». Gran parte de ella fue apreciada desde muy temprano por un público amplio, aunque de nivel superior al de los aficionados a Bonilla, Ledesma o las coplas de ciego. Un nivel no tanto de cultura como de sensibilidad. Los pocos que se resistieron a su encanto eran, por el contrario, gente empachada de lecturas y que tomaba por dogmas los tratados de retórica y poética, de los que los poetas, al menos en España, hacían caso omiso. Si hubiera alguna duda, bastaría repasar las Flores de romances nuevos, no dirigidas a un público restringido sino mayoritario y de cultura intermedia, a pesar de lo cual la presencia de Góngora en ellas es tan dominante como en las posteriores y más selectas de Espinosa.

No se nos oculta que lo dicho parece volver a la vieja contraposición del Góngora sencillo y popular frente al oscuro y exquisito de los poemas mayores. En lo que sigue intentaremos, una vez más, probar que el primero puede ser tan refinado y sutil como el segundo, y que su calidad es pareja. Por otra parte, no supone ningún exceso postular que la recepción influyera 
en el inacabamiento de algunas obras gongorinas, como el Panegírico, las Soledades o el Carlino, ni tampoco que Góngora no hubiera acometido su composición sin el respaldo de una fama cimentada en las obras anteriores. Tampoco será desacato decir que no siempre alcanza la misma altura: el Panegírico, contra lo que pensaba Pellicer, no es tan inspirado como el Polifemo, las Soledades o La Tisbe, varios romances de vena idealista tienen un interés mucho menor que otros humorísticos, y en cuanto a los poemas epidícticos, con excepciones llamativas y factura impecable, barajan tópicos trillados. Eso es natural. Lo insólito, en cambio, es que un poeta sea capaz de componer centenares de piezas perfectas, muchas de ellas espléndidas, aunque solo constituyan la mitad de su producción. Veamos ya cómo lo consigue, examinando algunos de sus procedimientos.

Uno de ellos es el poema-alegoría. Es bien sabido que la alegoría se usó en la edad media, luego decayó hasta ser recuperada o más bien reinventada, a veces en forma estrambótica, por el conceptismo sacro. Gracián parece aludir a ella cuando habla de «la enfadosa cárcel de una metáfora» ${ }^{3}$. Góngora tardó bastante en afrontar la alegoría, al menos la coextensiva del poema. El romance "Esperando están la rosa», de 1609, es un tour de force en que la primavera se describe como si fuera un palacio: la rosa es la reina, las espinas son archas, el clavel es príncipe de la sangre, el jacinto inscribe un lamento en sus pétalos, el jazmín espira ámbar, el narciso abandona la fuente... Sigue el lilio, cortesano celoso, mosquetas y clavellinas son damas de la reina, las azucenas pasan por dueñas de honor, las violetas por meninas, un laurel sirve de jaula a unos ruiseñores, un ciprés hace de guardadamas, y los estanques de bufones. Era casi imposible mantener las correspondencias a lo largo de 96 versos. Para no forzar las cosas, Góngora permite que el jacinto, el jazmín y el narciso queden libres de equivalencia, e incluso en la aproximación de los estanques como bufones enumera dos elementos válidos («en lo frío lo primero / que se me ha de conceder, / en el murmurar contino / y en el reírse también»), pero el tercero no cuadra: «en el pedir, y no agua, / que no es de agua su interés, / ni piden lo que no beben / por siempre jamás, amén». Aquí, si no nos engañamos, Góngora está describiendo el referente, es decir, los bufones, no el tenor de la imagen, que serían los estanques. La dificultad de mantener las correspondencias se pone de manifiesto cuando todo un Góngora es capaz de confundirse. Los versos 45-48 («Ámbar espira el vestido

3. «Crueldad es, que no arte, condenar una hora entera al que oye o al que lee, a la enfadosa cárcel de una metáfora... Ingeniosos son los Raguallos del Boquelino, pero no dejan de enfadar por la uniformidad de su alegoría» (Agudeza y Arte de ingenio, ed. de C. Peralta, J. M. Ayala y J. Ma Andreu, Zaragoza: Prensas Universitarias, 2004, II, p. 530; el fragmento pertenece al Discurso LI, que inicia el «Tratado segundo, de la agudeza compuesta»). 
/ del blanco jazmín, de aquel / cuya castidad lasciva / Venus hipócrita es»), a pesar de su carácter críptico, tuvieron éxito y fueron glosados por varios poetas. Parece ser que el aceite de jazmín, muy aromático, se consideró afrodisiaco desde antiguo sobre todo en la cultura oriental, aunque ni Plinio ni el Dr. Laguna dicen nada al respecto. El romance en cuestión, uno de los más celebrados de Góngora, pinta la corte en tono semijocoso, usándola como imagen chusca de un jardín, y reflejo no menos festivo de las correspondencias universales.

De 1610 son la siguientes décimas:

\section{DE LA TOMA DE LARACHE}

Larache, aquel africano
fuerte, ya que no galán,
al glorioso San Germán,
rayo militar cristiano,
se encomendó y no fue en vano,
pues cristianó luego al moro,
y por más pompa y decoro,
siendo su compadre él mismo,
diez velas llevó al baptismo
con muchos escudos de oro.
A la espańola el marqués
lo vistió, y dejar le manda
cien piezas que, aunque de Holanda,
cada una un bronce es.
De ellas les hizo después
a sus lienzos guarnición,
y viendo que era razón
que un lienzo espirase olores,
oliendo lo dejó a flores,
si mosquetes flores son.

Si el poema fuese de Ledesma, llevaría como subtítulo «en metáfora de un bautismo». Aquí la alegoría se mantiene sin decaimiento: Larache es un fuerte africano, y el término fuerte funciona a la vez como sustantivo y adjetivo; el marqués de San Germán lo hace cristiano, llevando diez velas al bautismo, con muchos escudos de oro: las diez galeras de la expedición, y los 120.000 ducados que según Cabrera se pagaron por la plaza al rey de Fez. El marqués lo vistió a la española, y le dejó cien piezas de holanda, 
para guarnecer sus lienzos: las piezas de artillería, de origen holandés, que defendían sus muros, junto con mosquetes, palabra igualmente bisémica que significa 'arcabuces', y también 'rosas silvestres', aceptando la restricción de v. 20, porque en realidad la palabra idónea sería mosquetas. No es quizá un gran poema, pero las correspondencias sí están bien buscadas, y el resultado final, más aún que en el romance anterior, es de suave sorna, en este caso hacia aquel efímero rayo de la guerra que fue el marqués de San Germán, primo y protegido del duque de Lerma, cuyo mérito se reduce a apadrinar un bautizo malgastando el dinero del erario.

Hacia 1612 compone Góngora la letrilla "Arroyo, ¿en qué ha de parar...?», que siempre se ha tenido por sátira contra don Rodrigo Calderón, y es acaso el único poema en que Góngora actualiza la equivalencia poeta = profeta, ya que los versos 5-8, repetidos tras cada mudanza, no pudieron acertar mejor en la diana, diez años más tarde:

\section{CONTRA UN PRIVADO}

C. Arroyo, ¿en qué ha de parar tanto anhelar y morir,

tú por ser Guadalquivir,

Guadalquivir por ser mar?

A. Carillejo, en acabar

sin caudales y sin nombres, para ejemplo de los hombres.

C. Hijo de una pobre fuente, nieto de una dura peña, a dos pasos los desdeńa tu mal nacida corriente; si tu ambición lo consiente, ¿en qué imaginas, me di? Murmura, y sea de ti, pues que sabes murmurar.

Arroyo, ¿en qué ha de parar, etc.

C. ¿Qué día tienes reposo?

¿A qué noche debes sueño?

Si corres tal vez risueño, siempre caminas quejoso; mucho tienes de furioso, aunque no en el tirar cantos, 
y así tropiezas en tantos cuando te quies levantar.

Arroyo, ¿en qué ha de parar, etc.

C. Si tu corriente confiesa

sin intermisión alguna

que la cabeza en la cuna

y el pie tienes en la huesa,

¿qué fatal desdicha es esa

en solicitar tu daño?

Pésame que el desengaño

la vida te ha de costar.

Arroyo, ¿en qué ha de parar, etc.

Góngora, hijo de su tiempo, no es partidario de los ascensos por el atajo. La alegoría aquí montada, muy distinta del concepto inicial de la segunda Soledad, donde también se habla de un arroyo que se apresura hacia el mar, recuerda igualmente, aunque sin mencionarlo, el consabido ejemplo de la mariposa que porfía en buscar su ruina (vv. 42-43 sobre todo), y se adapta como un guante al caso de don Rodrigo Calderón, quien no solo trepó sin escrúpulos en los resortes del poder, sino que, habiendo nacido en Amberes, quiso hacerse pasar por hijo natural del duque de Alba, renegando de sus propios padres. Las tres estrofas dicen lo mismo con poca variación, pero el poema va progresando en intensidad desde el nacimiento del arroyo hasta su fin, con los pasos de ambición, murmuración, quejas y locuras. Si es verdad la leyenda que acompaña al soneto "No más moralidades de corrientes», la letrilla le habría costado la cárcel a Góngora: tan mordaz se consideró su sátira contra un prócer que, curiosamente, acabaría por ser su amigo y protector.

Por odiosas que sean las comparaciones, interesa ver qué puede hacer un poeta normal con un tema como este. Lo encontramos en una letrilla de Antonio Hurtado de Mendoza impresa en la Primavera y Flor de 1621:

No corras, arroyo, vfano, que no es tu caudal eterno, que si te lo dio el inuierno, te lo quitará el verano.

Naciste escondidamente de vna humilde y pobre roca, cuya agua, por ser tan poca, 
no te dio nombre de fuente.

Si del mundo la corriente

lleuas con tus ondas breues,

y guerra a los campos mueues

con tu límite tirano,

no corras, arroyo, vfano, etc.

El arroyo aquí recibe una admonición: no debe correr orgulloso, puesto que su caudal, que nació como hilo de agua, desaparecerá en verano. El símbolo, no alegoría, es aplicable a quienquiera que se confíe en la perduración del poder o de los bienes. Ese es todo el partido que el poeta le saca ${ }^{4}$.

Volviendo a Góngora, veamos una décima, de 1624, que hace uso no menos magistral de la alegoría:

\title{
A UN CABALLERO QUE ESTANDO CON UNA DAMA \\ NO PUDO CUMPLIR SUS DESEOS
}

\author{
Con Marfisa en la estacada \\ entrastes tan mal guarnido, \\ que su escudo, aunque hendido, \\ no lo rajó vuestra espada. \\ 5 ¿Qué mucho, si levantada \\ no se vio en trance tan crudo, \\ ni vuestra vergüenza pudo \\ cuatro lágrimas llorar, \\ siquiera para dejar \\ 10 de orín tomado el escudo?
}

La alegoría no puede ser más transparente ni estar mejor trazada, dentro del manido tópico de las batallas de amor, y viene a ser un eco más del Orlando furioso en nuestra poesía, aunque en realidad deja al hipotexto reducido a mero recurso lingüístico: cualquier guerrera intrépida, sin más precisiones. Si no existiera el epígrafe, el deleite mayor sería descubrir el paralelo a medida que se va leyendo. Entre las alegorías de Ledesma y esta han pasado pocos años, pero hay un abismo.

4. Luchando contra un tenaz malentendido de nuestra historia literaria, hemos usado el mismo procedimiento comparativo en nuestro artículo «El conceptismo de Góngora y el de Quevedo", Il Confronto Letterario, 52 (2009), pp. 99-123. 
Por supuesto, en Góngora se encuentran multitud de alegorías que no abarcan un poema completo, sino una estrofa o un grupo de versos. Baste el siguiente ejemplo de la letrilla "Que pretenda el mercader», de 1610:

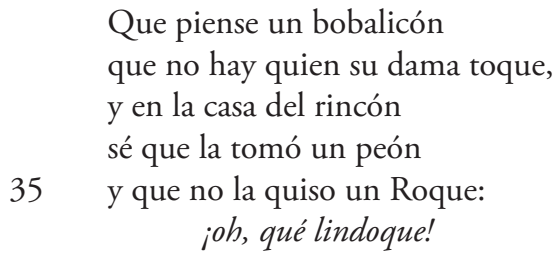

Parece que se está hablando en lenguaje directo, pero todo el campo semántico es uniforme y bisémico: dama, casa del rincón, tomar, peón y roque designan también los trebejos y jugadas del ajedrez. Otros casos ofrecen, más que alegoría, una metáfora ramificada, una isotopía que extiende sus zarcillos por varios versos hasta agotarse. Así sucede en el romance a santa Teresa, de 1614:

De la semilla, caída
no entre espinas ni entre piedras,
que acudió a ciento por uno
a la agradecida tierra,
media fue, y media colmada,
la santa que hoy se celebra
de Ávila, según dispone
ley de medidas expresa,
bien que de semilla tal
no solo quiere ser media,
sino costal de buriel,
cuando no halda de jerga, etc.

La parábola del sembrador habla de semilla que fructifica, el grano se recoge en medias fanegas, la ley mandaba que la medida marco fuese de Ávila, patria de la santa, y esta no se conforma con ser media, sino costal de buriel, paño burdo con que se vestían los carmelitas. Aquí Góngora no busca la gran poesía, sino más bien lo contrario: intenta remedar las imágenes, siempre algo forzadas, propias del conceptismo sacro, puesto que presentó este romance a nombre del vicario de Trasierra, en un certamen de cuyo jurado formaba parte. En lugar de hurtar el estilo a un ciego, como dice en otra ocasión, aquí se disfraza de cura de aldea, y finge estar exprimiendo su mollera. 
En 1618 dispara contra Lope de Vega la siguiente sátira:

\author{
En vuestras manos ya creo \\ el plectro, Lope, más grave, \\ $\mathrm{y}$ aun la violencia süave \\ que a los bosques hizo Orfeo, \\ 5 pues cuando en vuestro museo \\ por lo blando y cebellín \\ cerdas rascáis al violín, \\ no un árbol os sigue o dos, \\ mas descienden sobre vos \\ 10 las piedras de Valsaín.
}

Todo el poema surge de una anécdota: un loco llamado Valsaín dio en apedrear la casa de Lope. Góngora en seguida ve el concepto por ironía: Lope es como Orfeo, que con su canto atraía las piedras. De paso, claro, se las arregla para dar un alfilerazo al concubinato de Lope con Marta de Nevares, aludida elegantemente con el término cebellín del v. 6. Tal tratamiento requiere mucha destreza, y lo redondea el hecho de que Valsaín designa también un lugar pedregoso en la sierra, cerca de La Granja, donde los reyes solían cazar. La malicia consiste en dejar sentado, de modo subrepticio, que el atraer piedras es efecto de dos causas contrarias: cantar bien y cantar mal, lo que convierte a Lope en un Orfeo al revés. Un uso igualmente chusco de esa leyenda, combinada con la de Anfión, aparece en el romance «Aunque entiendo poco griego", al describir a Leandro:

$$
\begin{aligned}
& \text { Citarista, aunque nocturno, } \\
& \text { y Orfeo tan desgraciado } \\
& \text { que nunca enfrenó las aguas } \\
& \text { que convocó el dulce canto, } \\
& \text { puesto que ya de Anfión } \\
& \text { imitando algunos pasos, } \\
& \text { llamó a sí muchas más piedras } \\
& \text { que tuvo el muro tebano. }
\end{aligned}
$$

Quevedo en el romance "Orfeo por su mujer / dicen que bajó al infierno" se limita a repetir la idea en tono hiperbólico: «Montañas, riscos y piedras / su armonía iban siguiendo, / y si cantara muy mal / le sucediera lo mesmo» (ed. Blecua, $\mathrm{n}^{\circ} 765$ ).

Lo antes comentado acerca de Valsaín es uno de los procedimientos gongorinos que vamos a denominar, sin buscar términos más sabios, refuerzo del significante. El loco podía ser cualquier otro: Vinorre, por ejemplo, que 
existió en aquel tiempo, y que se menciona en un soneto también asestado a Lope. Sin embargo, Góngora quizá no habría escrito su sátira porque el significante Vinorre no pertenece, como Valsaín, al paradigma bosques, árbol, piedras, que estructura el concepto órfico. Algo similar vemos en la cabeza de la célebre letrilla: "Aprended, Flores, en mí, / lo que va de ayer a hoy» (1621). Las cinco mudanzas que comentan esa cuarteta, la más glosada de la literatura espańola, recorren la maravilla, el clavel, el jazmín, el alhelí y el girasol, desde la más efímera a la más duradera. Pero el estribillo apunta asimismo al marqués de Flores de Ávila, quien había visitado al poeta cuando estaba enfermo. Aunque no se puede saber si Góngora hubiera escrito de todas maneras la letrilla en otras circunstancias, lo cierto es que, una vez leído el epígrafe, quien resulta aleccionado por la fugacidad de la maravilla no son solo las flores sino el marqués, de ahí que convenga editar Flores con mayúscula.

Probablemente ese cuidado extremo en la construcción del concepto es también el caso de unos versos en los tercetos «Mal haya el que en señores idolatra», de 1609. El poeta, harto de Madrid, espera la mula que lo ha de llevar a su tierra, y se complace en describir la aurea mediocritas que suele disfrutar en su huerta cordobesa, hablando de sí mismo en tercera persona:

Sobre el aljófar que en las hierbas luce

95 o se reclina o toma residencia a cada vara de lo que produce.

Apelando de nuevo a la conmutación, imaginemos que donde dice vara pusiera rama. La metáfora tomar residencia funcionaría igual, puesto que significa 'pedir cuentas': el poeta pide cuentas a sus frutales. Ahora bien, aunque lo propio de un frutal es tener ramas y no varas, el poeta elige esta segunda opción, porque la vara es también el signo de un cargo, como el de juez, gobernador o algo similar, y es a ellos a quienes se les tomaba residencia una vez cesados. Las expresiones vara y tomar residencia pertenecen al mismo campo semántico, por tanto son las más adecuadas.

Un nuevo ejemplo nos proporciona el romance «Tenemos un doctorando», de 1611. El aspirante, sobrino del administrador del Hospital Real de Granada, según el vejamen, le habría pedido ayuda para doctorarse. Luego ańade:

45 Correspondiole su tío $y$, aunque algo escrupuloso de su talento, a la costa jinetes ofreció de oro. 
Imaginemos que en lugar de jinetes hubiera dicho escudos. De hecho eso es lo que significa: el tío ofrece correr con el costo, es decir, con los gastos. Pero Góngora desecha costo y prefiere el sinónimo costa; y en lugar de escudos escribe jinetes. La razón es que existían unos jinetes de costa, llamados atajadores, que vigilaban el movimiento de los barcos enemigos. El sintagma de oro es una de esas restricciones o "virtudes pedagógicas» de que habló Mercedes Blanco, y que deja las cosas en su sitio, después de habernos permitido dar una vuelta con la imaginación por el litoral andaluz, siempre en guardia ante las incursiones de los berberiscos.

Nada más trillado que llamar nieve a la piel blanca de una mujer. Con todo, Góngora no se priva de hacerlo al describir una moza en el romance «Dejad los libros ahora», de 1590, pero con este añadido: «La blanca y hermosa mano, / hermoso y blanco alguacil / de libertad y de bolsa, / es de nieve y de neblí» (vv. 37-40). He ahí, pues, renovado el tópico: la mano es blanca como la nieve, término que atrae fonéticamente a nebli, ave rapaz; de esa forma, si la libertad peligra con la blancura, la bolsa también. La paronomasia nieve I neblí no se limita a jugar con la forma de la expresión, sino también con la del contenido, es a la vez figura de lenguaje y de pensamiento. Los epítetos blanco y hermoso excluyen la connotación alguacil de moscas que, según Covarrubias, designa a una araña ponzoñosa, y eso a pesar del doble sentido que ya entonces podía tener mosca. En el romance «Al pie de un álamo negro» (1615), al hidalgo Rengifo, cuando está remendando sus calzas cerca de Esgueva, unas cigarras le recuerdan el sol que hace. Pero Góngora en esa ocasión prefiere el italiano: «le cantan el sol que fa»; así los tres términos no gramaticales del verso, en cuanto al significante, quedan emparentados por la isotopía musical, las notas sol y fa de la escala.

El conde de Salinas y marqués de Alenquer, poeta estimado en su tiempo y amigo de Góngora, compuso el soneto "Estas lágrimas vivas que corriendo» sobre el tema cancioneril del silencio impuesto al amante no correspondido. Estos son sus tercetos:

\footnotetext{
Vos podéis descifrar algún suspiro

10 sin que yo pierda el nombre de callado, más palabra no oiréis de mis enojos;

pero tendré por fuerza, cuando os miro, remitido el deciros mi cuidado a la lengua del agua de mis ojos 5 .
}

5. Antología poética, ed. de T. J. Dadson (Madrid: Visor, 1985), p. 46. 
El último verso resume esa situación en que son las lágrimas, y no las palabras, las que hablan. La imagen remata con suavidad un soneto cuya fecha no conocemos. Sea, pues, intercambio amistoso o poligénesis, el verso tal cual cierra asimismo el soneto "A la Mamora, militares cruces", donde Góngora se burla de los señores que acudieron a aquella empresa más preocupados de su bienestar que de la milicia. He aquí cómo uno de ellos se despide de su dama:

-... ¡ Oh tú, mi dulce dueño!

10 Partiendo me quedé, y quedando paso a acumularte en África despojos.

- ¡Oh tú, cualquier que la agua pisas leño!: escuche la vitoria yo o el fracaso a la lengua del agua de mis ojos.

Se supone que el segundo terceto es la respuesta de la dama, dirigiéndose al barco, y deseando escuchar nuevas de la operación «a la lengua del agua de mis ojos». El verso se ha transmutado por obra y gracia de la bisemia: si por un lado significa 'lágrimas', como en el soneto del conde, por otro lengua del agua, según Covarrubias, vale 'orilla de la mar', el lugar más idóneo para despedir o recibir a quien se embarca, y la connotación es inevitable. Por ello, al mismo tiempo, agregando el sintagma que sigue, resulta imposible no entender algo así como 'a la orilla de mis ojos', o si esta imagen suena demasiado moderna, otra lectura: 'escuche yo de mis ojos la victoria o el fracaso a la lengua del agua', y aún cabe que el sintagma mis ojos retenga su habitual sentido erótico. Sea como fuere, resulta indudable que la complejidad semántica no es casual. La que era imagen plana en el conde de Salinas, gracias a la alquimia gongorina, se ha convertido en algo de un espesor inusitado, casi excesivo.

Veamos ahora otro caso probable de difusión en los conceptos gongorinos, para seguir destacando la diferencia de tratamiento. La siguiente letrilla, de 1620, habla de Santiago el Verde, una fiesta que se celebraba el primero de mayo en el Sotillo del Manzanares, frente a la dehesa de Arganzuela. Fijémonos solo en su cabeza:

\author{
No vayas, Gil, al Sotillo, \\ que yo sé \\ quien novio al Sotillo fue, \\ que volvió después novillo.
}


Aquí sucede un fenómeno curioso, que podría resumirse en forma de ecuación verbal: novio + Sotillo = novillo, una ecuación que incluso funciona fonéticamente, y que lo hizo históricamente, puesto que ir al Sotillo se consideró de mal agüero para la honra masculina. La rima generadora de la pareja Sotillo / novillo se mantiene además a lo largo del poema, de modo que, de alguna manera, resuena en los versos de vuelta con los términos cuclillo, castillo y corrillo. Tanta sutileza, que sepamos, solo ha suscitado un par de ecos en Quevedo: «De su novio hará novillo / y así con él arará», dice la letrilla «Y no lo digo por mal» (ed. Blecua, n 650) y «Murió, en fin; el rey perdiose, / su novio quedó novillo» (romance «Marca Tulia se llamaba», ed. Blecua, $n^{\circ} 738$ ); un tercer eco aparece en Jacinto Alonso Maluenda: «Y dentro de pocos meses / hallaréis novillo el novio / paciendo con otros tales / en el Prado o en el Soto» (romance "La más resabida vieja», Cosquilla del gusto, ed. Juliá, p. 79). Ecos desabridos, huelga decirlo, que se limitan a la malicia de la paronomasia.

La coherencia conceptual en la poesía de Góngora es una constante más estudiada, y por ello no le dedicaremos mucho tiempo. En Polifemo y Soledades salta a la vista y contribuye a estructurarlos como grandes poemas. Veámosla en algún caso menor. En el romance "Aunque entiendo poco griego", al describir la casa de Hero, se dice que el castillo en que vivía era "una casa de descalzos / cernícalos de uñas negras / en las almenas crïados». Esto sucede al comienzo, vv. 16-18. Aparte de que casa de descalzos es frase hecha, aquí engañosa y solo traída por humor, se refiere a los hermanitos de Hero, caracterizados como polluelos e invención de Góngora. Luego viene la pintura de Leandro y el resto de la leyenda, hasta que los futuros amantes se encuentran en una romería, a la que los nińos no asisten, pero el poeta, sesenta versos después, no los olvida: «Los demás caballeritos / en la torre se quedaron, / cuál sin pluma y cuál con ella, / y todos de hambre pïando» (vv. 81-84). Por si fuera poco esto, lo que sigue continúa buen rato en el campo semántico ornitológico: a los ojos de Hero «se calaron luego / dos o tres torzuelos bravos / como a búho tal, y entre ellos / el abideno bizarro / pïola cual gorrión, / cacareola cual gallo, / arrullola cual palomo, / hízola ruedas cual pavo». Es como si Góngora, una vez puesta en marcha una imagen, tiñese los versos contiguos de los isótopos que de ella emanan. Dentro de los aspectos que vamos viendo hay hacia el final una copla que puede pasar inadvertida por su apariencia sencilla pero que encierra, a mi juicio, algo prodigioso. Hero y Leandro conciertan la forma de juntarse, y apenas anochece, "cuando el mozuelo orgulloso / hacia el mar ya alborotado / un pie con otro se fue / descalzando los zapatos» (vv. 185-188). Si nos fijamos en los últimos versos, el sintagma se fue pertenece a la vez a dos 
verbos: ir y ser, este como auxiliar de una perífrasis: Leandro se fue hacia el mar (verbo ir), y se fue descalzando los zapatos (verbo ser) de la manera que lo hace alguien cuya mirada está fija en cosa más importante: no con las manos, sino procurando que un pie descalce al otro, como todos hemos hecho alguna vez. Esta imagen tan gráfica puede ponerse a la par de aquella en la que Polifemo, espantando las cabras a pedradas, provoca la separación y huida de Acis y Galatea, lo que Góngora comenta con un símil sabroso: un campesino que, ojeando las aves de su sembrado, ahuyenta sin querer una pareja de liebres oculta en un surco («tal redimiendo de importunas aves / incauto meseguero sus sembrados, / de liebres dirimió copia así amiga / que vario sexo unió y un surco abriga», vv. 477-480). Cosas como estas no pudo Góngora sacarlas de los libros, sino de la observación minuciosa de la realidad.

El precepto de la coherencia no sabría decir dónde lo aprendió Góngora, porque sus coetáneos lo practican mucho menos, y él lo acata desde muy joven. Otro buen ejemplo lo encontramos en La Tisbe. El romance arranca diciendo que Babilonia es famosa «...por los dos amantes / desdichados, hijos suyos, / que muertos y en un estoque / han peregrinado el mundo" (vv. 5-8). Retengamos esto: Píramo y Tisbe, muertos y en un estoque. En una letrilla muy temprana, de 1581, se había acordado de ellos para exhibir su epicureísmo: «Pues Amor es tan cruel / que de Píramo y su amada / hace tálamo una espada / do se junten ella y él, / sea mi Tisbe un pastel, / y la espada sea mi diente, / y ríase la gente». La espada con que ambos amantes se atraviesan es aquí un tálamo, ya que sirve para unirlos. Treinta y siete años después, al final de la fábula se nos narra el suicidio de Píramo diciendo que desnudó su acero

...y no como el otro Mucio
asó intrépido la mano,
sino el asador tradujo
por el pecho a las espaldas.
$430 \quad$ ¡Oh tantas veces insulso
cuantas vueltas a tu hierro
los siglos darán futuros!

Lo que era espada, después de convertirse en estoque (vv. 5-8) y verdugo (v. 356), parece acabar sus metamorfosis como asador (v. 428), pero no: en realidad acaba como hierro (v. 431), a fin de permitir la homofonía con yerro dentro de la frase comparativa: 'eres tantas veces insulso cuantas vueltas darán a tu yerro los siglos futuros'. Y como los asadores son hierros que 
deben girar para que algo quede bien asado, nosotros, lectores de los siglos futuros, ocupándonos del yerro que hizo morir a Píramo y Tisbe, en el fondo seguimos volteando el asador en que ellos atravesados peregrinan el mundo, tal como se postulaba al comienzo del poema. No es posible dejar de evocar el Julio César de Shakespeare (III, i), cuando Casio imagina que la escena del magnicidio será repetida durante mucho tiempo. A través del protagonista dramático o del narrador de la fábula, Shakespeare y Góngora se complacen por igual en imaginar la repercusión de los hechos presentados, como si la posteridad literaria estuviera ya embebida en ellos.

Otro precepto bien observado por Góngora en toda su obra es el de la densidad, o concentración, de manera que sus versos no solo no contengan palabras ociosas, sino que incurran, llegado el caso, en braquilogía. Este recurso, que regula la información que debe transmitir cada pasaje, se relaciona naturalmente con la dificultad, pero también con la eficacia. Es famoso el pasaje en que Góngora describe el ruiseñor, en los tercetos de 1609: «Prodigio dulce que corona el viento, / en unas mismas plumas escondido / el músico, la musa, el instrumento». Una descripción intelectual, que no se fija en la apariencia del ave sino en su canto. Los elogios de Salcedo Coronel suben aquí de tono: «iOh justamente aplaudido en la estimación de todos! Digno te hace este terceto de inmortales alabanzas. ¿Quién de los antiguos te igualó en esta sentencia? ¿Cuál de los modernos sin invidia llegará a examinarla?» ${ }^{6}$ Salcedo no explica el porqué de su entusiasmo, dando a entender que no hace falta; puesto que apenas hay ahí lenguaje figurado, son los versos segundo y tercero -este con asíndeton- los que suponen una concentración insólita, que haría las delicias de Olivier Messiaen; el gran compositor, como se sabe, empezó sus trabajos preparatorios del Catalogue d'oiseaux después de que su maestro Paul Dukas lo animase a ello recordándole que los pájaros son los verdaderos músicos, los únicos que lo son por naturaleza. Quevedo describió un jilguero en la letrilla «Flor que cantas, flor que vuelas» (ed. Blecua, $\mathrm{n}^{\circ}$ 206), obviamente inspirada en ese terceto de Góngora. Destacaremos solo aquellos momentos en que se acerca a él: «En un átomo de pluma, / ¿cómo tal concento cabe? / ¿Cómo se esconde en una ave / cuanto el contrapunto suma? / ¿Qué dolor hay que presuma / tanto mal de su rigor, / que no suspenda el dolor / al iris breve que canta, / llena tan chica garganta / de orfeos y de vigüelas?... / Voz pintada, canto alado, / poco al ver, mucho al oído, / ¿dónde tienes escondido / tanto instrumento templado?»,

6. Segunda parte del tomo segundo de las Obras de don Luis de Góngora. Comentadas por don García de Salzedo Coronel, cauallero de la Orden de Santiago (Madrid: Diego Díaz de la Carrera, 1648), p. 266. 
etc., porque la letrilla tiene 37 versos, 58 si se cuentan los estribillos. Algún espontáneo, creyéndola demasiado larga, la redujo a una décima, la dedicó al ruiseñor, a pesar de que el plumaje de este no tiene nada de «ramillete», y la publicó en las Poesías varias de Alfay (1654) («Flor con voz, volante flor», ed. Blecua, $n^{\circ}$ 208).

Como excepción tomaremos un ejemplo de la segunda Soledad, luego veremos por qué. El canto amebeo de Lícidas y Micón se abre con esta estancia del primero:

$$
\begin{aligned}
& \text { «iA qué piensas, barquilla, } \\
& \text { pobre ya cuna de mi edad primera, } \\
& \text { que cisne te conduzgo a esta ribera?: } \\
& 445 \text { a cantar dulce y a morirme luego. } \\
& \text { Si te perdona el fuego } \\
& \text { que mis huesos vinculan, en su orilla } \\
& \text { tumba te bese el mar, vuelta la quilla». }
\end{aligned}
$$

El joven pescador consigue meter en siete versos la leyenda de los cisnes cantores antes de morir, su nińez en la pobre barca, su amor sin esperanza, y su muerte, cremación y enterramiento en la misma barquilla convertida en urna, casi se podría decir en naveta, por usar el término arqueológico. Se trata de un momento culminante en el poema, y así no será muy piadoso alegar el pasaje donde Quevedo busca una condensación similar, aunque sea en tono festivo. El romance "En el retrete del mosto» (ed. Blecua no 745), siguiendo la anécdota referida por Cicerón, Séneca, Plutarco o Diógenes Laercio, pinta en 188 versos el encuentro entre Alejandro y Diógenes. Cuando el primero pregunta al segundo qué quiere pedirle, este le responde:

$$
\begin{aligned}
& 145 \text {...Pocos temen mis concomios, } \\
& \text { muchos tiemblan tus escuadras: } \\
& \text { déjame con mi barreńo } \\
& \text { y vete con tus tïaras; } \\
& \text { que yo, vestido de un tiesto, } \\
& 150 \text { doy dos higas a la Parca, } \\
& \text { pues tengo en él sepultura, } \\
& \text { después que palacio y capa. }
\end{aligned}
$$

La última copla es buena muestra también de esa concentración que, en general, se echa de menos en la poesía de Quevedo, y, pese a su tono opuesto, no deja de recordar la estancia de las Soledades.

Dentro de la polémica suscitada por los grandes poemas gongorinos hay varias defensas en verso, una de ellas debida al conde de Saldaña, segundo 
hijo del duque de Lerma, mecenas y presidente de una academia literaria. Góngora, que en 1614 aún vivía en Córdoba, tuvo que sentirse halagado por el hecho, y mostró su agradecimiento en la siguiente décima:

\author{
Royendo, sí, mas no tanto, \\ el mar con su alterno diente \\ el escollo está eminente \\ que del cíclope oyó el canto, \\ 5 como a sí la invidia, en cuanto \\ cisne augustamente dino \\ de sitïal cristalino \\ su pluma hace elegante, \\ si bastón no de un gigante, \\ 10 báculo de un peregrino.
}

Pocos poemas pintarán tantas cosas como este en solo diez octosílabos: paisaje marino con Polifemo entonando su canto, el emblema de la envidia, un cisne cuya pluma sirve para evocar a los protagonistas de Polifemo y Soledades, y para elogiar a un noble que además era poeta. La restricción de v. 9 indica también la contención de Góngora al manejar la hipérbole.

Por último, vamos a examinar la paronomasia, algo que Góngora, en principio, comparte con poetas, prosistas y oradores, y de la que ya vimos algún ejemplo: una figura simple de tipo verbal, más común en el estilo satírico o jocoso, y que no suele ir más allá de la mera ocurrencia o exhibición de ingenio. Dicho de otra forma, si la paronomasia aparece en un texto, es solo porque un significante atrae a otro con el que está asociado fonéticamente en el mismo paradigma; el escritor selecciona ambos y los hace compartir sintagma, esperando que del choque de similitudes y diferencias surja la sorpresa. Góngora nunca se va a contentar con ella, sino que, con un peculiar tratamiento, convertirá la paronomasia en instrumento eficaz gracias a una motivación semántica que justifica la existencia de sus dos caras.

En el Diálogo entre un paje y una mula maliciosa, de Montemayor, se encuentra la siguiente paronomasia: «PAJE: ¿Por qué, no haziéndoos ultraje, / tenéys comigo baraja? / MULA: Porque quanto amo la paja, / tanto me aborrece un paje» ${ }^{7}$. No es imposible la poligénesis, pero como quiera que sea, el chiste reaparece en un romance temprano de Góngora, el que comienza «Desde Sansueña a París» (1588). En él, Pierres relata a Melisendra las nuevas de su tierra, y al hablar de la hermosa Flordelís, comenta que

7. Cancionero de 1562, ap. Poesía completa, ed. de J. B. Avalle-Arce y E. Blanco (Madrid: Fundación José Antonio de Castro, 1996), p. 701. 
«Bonetes la solicitan, / caballeros la pasean, / y ella dicen que da a un paje / lo que a tantos amos niega. / Dijo bien Dudón un día, / viendo dalle tantas vueltas: / -Basta, señores, que andamos / tras la paja muchas bestias». No hará falta insistir en el enriquecimiento que ha sufrido la simple paronomasia de Montemayor: paja se convierte en término bisémico por neologismo al significar también 'amante de un paje', y los rivales, puesto que andan tras ella, resultan ser bestias. La coherencia es total.

No menos muestra otro caso de paronomasia montado también sobre paje:

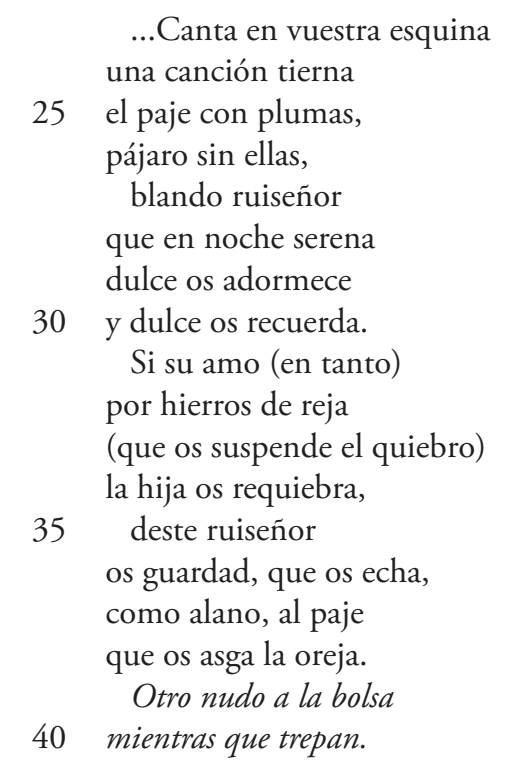

En estos versos hay dos paronomasias buscadas: paje / pájaro, vv. 25-26; y quiebro / requiebra, vv. 33-34. En la primera el paje recibe la imagen de pájaro, luego precisada en ruiseñor, para conectar con un término de la segunda: quiebro. De esta manera las dos paronomasias se entrelazan, no menos que la sintaxis de la tercera copla, cuya oración temporal (vv. 31 y 33), incrustada a trechos en la prótasis condicional, forma una sinquisis representativa asimismo del cruce de los hierros que forman la reja de la ventana. Por último, el paje-pájaro acaba comparado al alano, ya que uno y otro atacan las orejas ${ }^{8}$. En resumen, las paronomasias son aquí cualquier cosa

8. Por alguna razón, el término paje ha atraído más veces la paronomasia. Otro ejemplo puede verse en el siguiente poemilla: «Paxe, es mui digno de vltraje / paje que entiende tan mal; / que baxe sal, dixe, paje, / y pues no a baxado sal, / saluaje paje, sal vaje» (Cancionero de 1628, ed. de J. M. Blecua, Madrid: CSIC, 1945, p. 591). 
excepto juegos gratuitos u ornamentales; bien al contrario de lo habitual, sin ellas el poema no podría existir.

Una modalidad de paronomasia bien conocida es el políptoton, real o aparente, que Góngora cultiva desde joven sirviéndose de él como de embrague entre distintos campos semánticos. Por ejemplo, ¿cómo pasar de la alta política al epicureísmo más doméstico? He aquí la fórmula:

$$
\begin{aligned}
& \text { Traten otros del gobierno } \\
& \text { del mundo y sus monarquías, } \\
& \text { mientran gobiernan mis días } \\
& \text { mantequillas y pan tierno, etc. }
\end{aligned}
$$

Esta letrilla, «Ándeme yo caliente», es de 1581. En su penúltima estrofa también el políptoton, unido a la bisemia, sirve para acoplar dos asuntos absolutamente ajenos uno del otro:

$$
\begin{aligned}
& \text { Pase a media noche el mar, } \\
& \text { y arda en amorosa llama, } \\
& \text { Leandro por ver su dama, } \\
& \text { que yo más quiero pasar } \\
& \text { del golfo de mi lagar } \\
& \text { la blanca o roja corriente, } \\
& \text { y ríase la gente. }
\end{aligned}
$$

Aquí es el verbo pasar el que sirve de vínculo entre ambos planos, pero la isotopía se mantiene con los términos golfo (v. 35) y corriente (v. 36), tanto que casi se roza la alegoría. Al comienzo hemos recordado el primer terceto del soneto «El conde mi señor se fue a Napóles»:

$$
\begin{aligned}
& \text { Con pocos libros libres (libres, digo, } \\
& 10 \text { de expurgaciones) paso y me paseo, } \\
& \text { ya que el tiempo me pasa como higo. }
\end{aligned}
$$

Lo que hace don Luis en estos versos es mostrar que para él estas figuras no tienen secretos: hasta cinco términos juegan ahí con la paronomasia, la bisemia, y la epanortosis, entre ellos pasar.

De 1593 es la letrilla "A toda ley, madre mía», a la que pertenece esta estrofa, puesta en boca de una moza hábil en sacar partido a sus encantos:

$$
\begin{aligned}
& \text { Canónigos, gente gruesa, } \\
& \text { que tienen a una cuitada } \\
& \text { entre viejas conservada }
\end{aligned}
$$


como entre paja camuesa,

45 dan poco y piden apriesa, celan hoy, celan mañana:

muy humilde es mi ventana

para tanta celosía.

Aquí el políptoton es aparente, a pesar de la etimología común de celar y celosía, puesto que nadie sentía que fuesen de una misma familia semántica; otro texto áureo donde aparecen juntos celos y celosía, de fray Alonso de Cabrera, no establece la menor relación entre ambos términos 9 . En la letrilla el elemento que les sirve de enlace es ventana, ya que, en efecto, la gran celosía, o armazón de madera que permitía ver sin ser visto, corresponde a una ventana importante, que la joven rechaza, molesta por los celos de los canónigos que la tienen prisionera de dueńas (v. 43). Tal paronomasia ni siquiera se le ocurrió a Cervantes donde sería más esperable: en El celoso extremeño. El único que la retoma, con parentesco semántico, es de nuevo Góngora, en el primer acto de su comedia inacabada El doctor Carlino, cuando exclama Casilda: «Patria, adiós; posada mía, / nudoso balcón gallardo, / que los celos de Gerardo / vistieron de celosía» (vv. 1001-1004).

También usa el políptoton aparente la estrofa inicial de la letrilla «Los dineros del sacristán», de 1600:

Tres hormas, si no fue un par,

fueron la llave maestra

5 de la pompa que hoy nos muestra

un hidalgo de solar.

Con plumajes a volar

un hijo suyo salió

que asuela lo que él soló,

10 y la hijuela loquilla

de ámbar quiere la jervilla

que desmienta al cordobán.

Los dineros del sacristán

cantando se vienen y cantando se van.

9. Consultado al respecto nuestro amigo Pedro Álvarez de Miranda, sabio lexicógrafo, nos indica que en la comedia El esclavo de Roma, de Lope de Vega, figuran estos versos citados por el Diccionario Histórico de 1933: «Acaba, / que miras por celosía. / Apártala de tus ojos / si quieres ver tus engaños», lo que Terreros interpreta: «Del que tiene celos se suele decir que mira por celosía». Por nuestra parte, no hemos encontrado tal dicho, ni creemos que haya juego de palabras en el texto de Lope, cuyo sentido no lo necesita: 'tienes telarańas ante los ojos, te conviene quitártelas'. 
De nuevo tenemos aquí una sátira contra alguien entonado y de origen humilde: el zapatero remendón de antes hoy finge ser hidalgo de solar, frase hecha nada inocente, puesto que hidalgo de solar conocido es «el que tiene casa solariega de donde deciende» (Covarrubias), mientras que el solar de este hidalgo se relaciona más con las suelas que ha puesto a los zapatos. Por ello dice el v. 8 que su hijo «asuela lo que él soló», y la hija también se da importancia con servilla de ámbar. Toda la estrofa juega, pues, con el doble sentido de solar, y se mantiene dentro del ámbito semántico zapateril. Recuérdese que en aquel tiempo la cosa era más cómica que hoy, puesto que alguien de oficio mecánico, o con antepasados que lo practicaran, no podía obtener la ejecutoria de hidalguía. Por tanto el v. 6, un hidalgo de solar, tras los que le preceden, es un puro sarcasmo. Un eco, o caso paralelo, aparece en el entremés de La Castañera, de Castillo Solórzano. En él Juana, una castańera que quiere hacerse pasar por dama, es cortejada por varios menestrales, entre ellos un zapatero, que también intentan venderse por otra cosa, hasta que todos quedan al descubierto. El parlamento de Juana es este: «Y así, señor Galván, busco marido / de solar, no solar tan conocido / como el de vuesarced, que tengo dote / para que no ande oliéndome a cerote» ${ }^{10}$. El poeta de Tordesillas, como se ve, no acaba de perfilar la bisemia del sintagma; lo único que hace, con palabras como solar, cerote y más abajo solio, es recordar de cerca o de lejos el oficio de zapatero, a fin de que el pretendiente caiga en la cuenta de que no engańa a nadie.

En la misma línea está el conocido soneto de Góngora «Por tu vida, Lopillo, que me borres», fechable a partir de 1598. Este arremete contra la infeliz idea que tuvo Lope de ilustrar su Arcadia con el supuesto blasón de Bernardo del Carpio en el que figuran diecinueve torres, y que por tanto representa su propio linaje paterno, al que pertenecía también su tío el inquisidor Miguel Carpio. El soneto remata magistralmente gracias a una inesperada paronomasia:

No fabrique más torres sobre arena, si no es que, ya segunda vez casado, nos quiere hacer torres los torreznos.

El mismo ańo 1598 en que publicó su libro, Lope de Vega se había casado con Juana de Guardo, hija de Antonio de Guardo, carnicero de Madrid. De tal oficio, lo único que parecía útil para la sátira es su incompatibilidad con la pretensión de hidalguía, pero Góngora se las ingenia para sacar de él los

10. Las aventuras del bachiller Trapaza (Madrid: La Enciclopedia Moderna, 1905), p. 230. 
torreznos, un sustantivo derivado del verbo torrere 'tostar' y con aspecto de diminutivo, que si por un lado acredita cristiandad vieja, por otro de ningún modo puede ascender a motivo heráldico. Aunque hoy el lector necesita del paratexto que le aclare el avatar biográfico del dramaturgo, en la época era algo que nadie ignoraba ni en la corte ni en el resto de España.

Hemos repasado, pues, algunos poemas y recursos de Góngora que desde el primer momento habrán llamado la atención de sus lectores por su inusitada perfección, contribuyendo así a cimentar la fama del poetamesías. Fuera quedan, amén de los grandes poemas, obras maestras como "Hermana Marica», el soneto a Córdoba, el dedicado a don Cristóbal de Moura, la canción «¿Qué de invidiosos montes levantados...!", el romance de Angélica y Medoro, las coplas de Coridón, y tantas otras que apelan a procedimientos distintos de los aquí considerados. Nuestro objetivo era mostrar los más frecuentes en la poesía coetánea, y que, tal como dijo en su día Dámaso Alonso, son el nivel a partir del cual Góngora elabora su propio lenguaje. No vamos a postular que lo sacó de sí mismo ni menos que le cayó del cielo; al contrario, creemos que Góngora, por muy dotado que estuviera, y no hay duda de que lo estaba, aprendió de quien podía y sobre todo trabajó mucho en pos de esa perfección; la anécdota sobre las dos redacciones de la canción dedicada al sepulcro de Garcilaso, y los cambios introducidos en las Soledades tras la censura de Pedro de Valencia, son prueba de que, como atestiguan sus amigos, «se pasaba varios días en remirar un verso». Obras de extensión descomunal como las de Lope de Vega o Quevedo son imposibles de realizar con semejante criterio de autoexigencia. No solo cada ingenio persigue fines distintos, sino que los de Góngora sabemos que no tenían nada de extraliterario. Buscó mecenas, halagó próceres sacros y profanos, puesto que en su época era inevitable, pero ante todo fue fiel a sí mismo, como hicieron los más grandes de sus predecesores: Garcilaso y san Juan de la Cruz. 